\title{
Preparation of PtRu/Carbon Hybrids by Hydrothermal Carbonization Process
}

\author{
Marcelo Marques Tusi, Michele Brandalise, Olandir Vercino Correa, \\ Almir Oliveira Neto, Marcelo Linardi, Estevam Vitorio Spinacé* \\ anstituto de Pesquisas Energéticas e Nucleares - IPEN/CNEN - SP, \\ Av. Prof. Lineu Prestes, 2422, Cidade Universitária, 05508-900 São Paulo - SP, Brazil
}

Received: February 5, 2007; Revised: May 16, 2007

\begin{abstract}
$\mathrm{PtRu} /$ Carbon hybrids were prepared by hydrothermal carbonization process using glucose or starch as carbon sources and reducing agents and platinum and ruthenium salts as catalysts of carbonization process and metals source. The obtained PtRu/Carbon materials were characterized by SEM/EDX, TGA, XRD and cyclic voltammetry. The electro-oxidation of methanol was studied by cyclic voltammetry using the thin porous coating technique aiming fuel cell application. The catalytic activity was dependent of carbon source and time used in the synthesis.
\end{abstract}

Keywords: glucose, starch, hydrothermal carbonization, electrocatalyst, fuel cell

\section{Introduction}

Fuel cells employing directly alcohols as fuel (Direct Alcohol Fuel Cell - DAFC) are very attractive as power source for portable, mobile and stationary applications. The alcohol is fed directly into the fuel cell, without any previous chemical modification or purification and it is oxidized at the anode while oxygen is reduced at the cathode. This characteristic avoids problems related to production, purification and storage of hydrogen ${ }^{1-5}$.

The methanol has been considered the most promising alcohol, because it is more efficiently oxidized than others alcohols due the low complexity of its molecular structure. PtRu nanoparticles supported on carbon ( $\mathrm{PtRu} / \mathrm{C}$ electrocatalyst) has been considered the best electrocatalyst for methanol electro-oxidation. The catalytic activity of PtRu/C electrocatalysts is strongly dependent on the method of preparation and it is one of the major topics studied in Direct Methanol Fuel Cells (DMFC) $)^{6-8}$.

Studies have been shown that the use of carbon nanotubes and mesoporous carbon as support increase the performance of the $\mathrm{PtRu} / \mathrm{C}$ electrocatalysts, however, the synthesis of these supports are normally complex or involve harsh conditions ${ }^{9-11}$. Recently, the synthesis of metal/carbon nanoarchitectures by a one-step and mild hydrothermal carbonization process was reported using starch or glucose and metals salts ${ }^{12-14}$.

In this work, PtRu/Carbon materials with $\mathrm{Pt}: \mathrm{Ru}$ atomic ratio of 50:50 were prepared by hydrothermal carbonization process ${ }^{12-14}$ and tested as electrocatalysts for methanol electro-oxidation aiming fuel cell applications.

\section{Experimental}

$\mathrm{PtRu} /$ Carbon materials were prepared by hydrothermal carbonization process using $\mathrm{H}_{2} \mathrm{PtCl}_{6} \cdot 6 \mathrm{H}_{2} \mathrm{O}$ (Aldrich), $\mathrm{RuCl}_{3} \cdot x \mathrm{H}_{2} \mathrm{O}$ (Aldrich), glucose (Aldrich) and starch (Aldrich). An aqueous solution of glucose or starch was mixed with an amount of noble metals salts (glucose or starch/PtRu molar ratio of 82). Then, the solution was submitted to hydrothermal treatment at $200{ }^{\circ} \mathrm{C}$ for different times in a $110 \mathrm{~mL}$ capacity Teflon-lined stainless steel autoclave. The ob- tained solids were filtered, washed with ethanol and water and dried at $100{ }^{\circ} \mathrm{C}$ for 2 hours. The materials were thermally treated under argon atmosphere initially at $550^{\circ} \mathrm{C}$ for 4 hours and after this period at $900{ }^{\circ} \mathrm{C}$ for 3 hours.

The XRD analyses were performed using a Rigaku diffractometer model Multiflex using $\mathrm{Cu} \mathrm{K} \alpha$ radiation source $(\lambda=0.15406 \mathrm{~nm})$.

The atomic ratios were obtained by EDX analysis using a scanning electron microscope Phillips XL30 with a 10 and $20 \mathrm{keV}$ electron beam and equipped with EDAX DX-4 microanaliser.

The carbonization yield (wt. (\%)) was calculated considering that all carbon atoms of glucose or starch were converted on a carboneous structure.

The PtRu metal loading (wt. (\%)) was determined by thermogravimetric analysis (TGA) using a Shimadzu D-50 instrument and platinum pans. Heating rate of $5^{\circ} \mathrm{C} / \mathrm{min}$ was employed under dry oxygen $(20 \mathrm{~mL} / \mathrm{min})^{15}$.

Electrochemical studies of electrocatalysts were carried out using the thin porous coating technique $\mathrm{e}^{5,16,17}$. An amount of $20 \mathrm{mg}$ of the electrocatalyst was added to a solution of $50 \mathrm{~mL}$ of water containing 3 drops of a $6 \%$ solution polytetrafluoroethylene (PTFE) suspension. The resulting mixture was treated in an ultrasound bath for 10 minutes, filtered and transferred to the cavity $\left(0.40 \mathrm{~mm}\right.$ deep and $0.47 \mathrm{~cm}^{2}$ area) of the working electrode. The quantity of electrocatalyst in the working electrode was determined with a precision of $0.0001 \mathrm{~g}$. In voltammetry cyclic experiments the current values (I) were expressed in amperes and were normalized per gram of platinum $\left(\mathrm{A}_{\mathrm{P}_{\mathrm{Pt}}}{ }^{-1}\right)$. The quantity of platinum was calculated considering the mass of the electrocatalyst present in the working electrode multiplied by its percentage of platinum. The reference electrode was a RHE and the counter electrode was a platinized Pt plate. Electrochemical measurements were made using a Microquimica (model MQPG 01, Brazil) potenciostat/galvanostat coupled to a PC and using the Microquimica software. Cyclic voltammetry was performed in a 0.5 mol. $\mathrm{L}^{-1} \mathrm{H}_{2} \mathrm{SO}_{4}$ and $0.1,0.5$ and 1.0 mol.L $\mathrm{L}^{-1}$ methanol in $0.5 \mathrm{~mol} . \mathrm{L}^{-1} \mathrm{H}_{2} \mathrm{SO}_{4}$ solutions saturated with $\mathrm{N}_{2}$. For comparative purposes a commercial PtRu/C 
E-TEK (20 wt. (\%), Pt:Ru molar ratio 50:50, Lot \# B0011117) was used.

\section{Results and Discussion}

$\mathrm{PtRu} /$ Carbon materials were prepared by hydrothermal carbonization process using glucose or starch acts as the carbon sources and reducing agents, and platinum and ruthenium salts as catalysts for the carbonization process and source of the metals to be encapsulated ${ }^{12}$. When starch was used as carbon source, its partial hydrolysis leads to glucose units, which acts as reducing agent for noble metals ${ }^{12}$. The carbonization yield using glucose and starch as carbon sources reached 78 and 68 wt. (\%), respectively, after 6 hours of reaction time. Using starch as carbon source and increasing the reaction time to 12 hours the carbonization yield increased to $90 \mathrm{wt}$. (\%). The PtRu/Carbon materials as-synthezised did not show any activity for methanol electro-oxidation probably due to an incompletely polymerization and carbonization of the carbon sources in the reaction conditions ${ }^{12}$. In order to obtain a graphitic structure, the materials were further treated at $900{ }^{\circ} \mathrm{C}$ and a weight loss of 51 and $52 \%$ were observed for materials prepared using glucose and starch after 6 hours of reaction time, respectively. A weight loss of $59 \%$ was observed for the material prepared using starch after 12 hours of reaction time. After thermal treatment at $900{ }^{\circ} \mathrm{C}$ the $\mathrm{Pt}: \mathrm{Ru}$ atomic ratios of the obtained materials, determined by EDX analysis, were similar to the nominal atomic ratios used in preparations (Table 1). The PtRu loading (wt. (\%)), determined by TGA analysis ${ }^{15}$, showed the presence of $5 \mathrm{wt}$. (\%) of metals for materials prepared using glucose and starch after 6 hours of reaction time and $7 \mathrm{wt}$. (\%) for the material prepared using starch after 12 hours of reaction time (Table 1 and Figure 1).

The $\mathrm{X}$ ray diffractograms of $\mathrm{PtRu} /$ Carbon materials as-synthesized and after thermal treatment were shown in Figure 2. The diffractograms of as-synthesized materials showed a broad peak at about $2 \theta=20^{\circ}$ associated to the carbon material. The material prepared using glucose showed peaks at about $2 \theta=40^{\circ}, 47^{\circ}, 67^{\circ}$ and $82^{\circ}$, that are associated to the (111), (200), (220) and (311) planes, respectively, of the fec structure of platinum and platinum alloys ${ }^{18,19}$. The materials prepared using starch as carbon source showed the peaks corresponding to fcc structure broader than the ones observed for the material prepared using glucose, which suggest that the metal nanoparticles formed in these materials were smaller than the one formed in the material prepared using glucose (Figure 2a). After thermal treatment (Figure 2b) in all diffractograms the peak corresponding to the carbon material was shifted to higher $2 \theta$ angle and the peaks corresponding to fcc structure of Pt and Pt alloys become narrow and sharp indicating an increase of the average nanoparticle size. The (220) reflections of Pt (fcc) crystalline structure were used to calculate the average nanoparticle size according to Scherrer formula ${ }^{18}$ and the calculated values are in the range of 9-11 nm (Table 1). After thermal treatment it was also observed in all diffractograms a peak at about $2 \theta=44^{\circ}$ attributed to a separated ruthenium phase ${ }^{19}$. SEM images revealed the materials have morphology of spheres for all prepared samples (Figure 3).

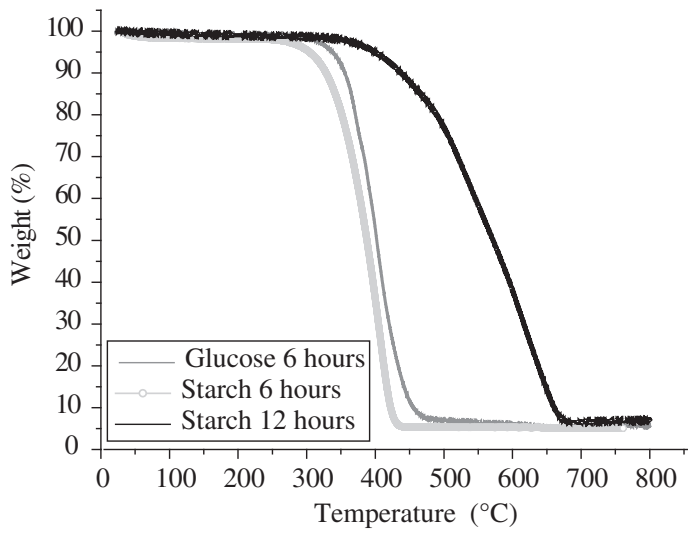

Figure 1. Thermogravimetric analysis of PtRu/Carbon materials after thermal treatment under dry oxygen $(20 \mathrm{~mL} / \mathrm{min})$ and heating rate of $5{ }^{\circ} \mathrm{C} / \mathrm{min}$.

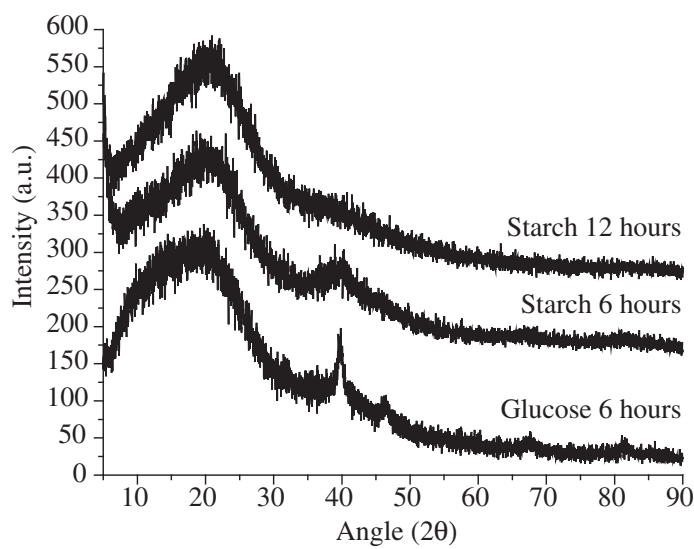

(a)

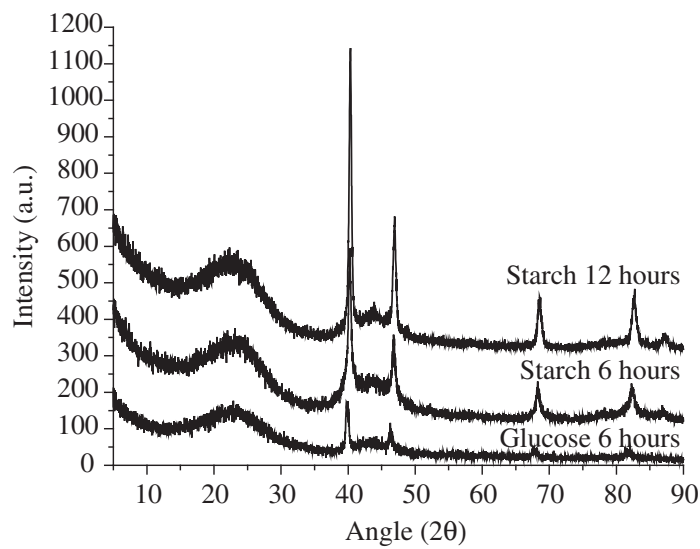

(b)

Figure 2. $\mathrm{X}$ ray diffractograms of $\mathrm{PtRu} / \mathrm{Carbon}$ materials (a) as-synthesized and (b) after thermal treatment.

Table 1. Pt:Ru atomic ratios, average particles size and PtRu metal loading of PtRu/Carbon materials $\left(200{ }^{\circ} \mathrm{C}\right.$, glucose or starch/PtRu molar ratio of 82 and $\mathrm{Pt}:$ Ru nominal atomic ratio of 50:50).

\begin{tabular}{cccccc}
\hline Carbon source & $\begin{array}{c}\text { Synthesis time } \\
(\mathrm{h})\end{array}$ & $\begin{array}{c}\text { Carbonization yield } \\
(\%)^{1}\end{array}$ & $\begin{array}{c}\text { Atomic ratio Pt:Ru - EDX }{ }^{2} \\
\begin{array}{c}\text { PtRu Metal loading } \\
(\text { wt. }(\%))^{2}\end{array}\end{array}$ & $\begin{array}{c}\text { Particle size } \\
(\mathrm{nm})^{2,3}\end{array}$ \\
\hline Glucose & 6 & 78 & $44: 56$ & 5 & 9 \\
Starch & 6 & 68 & $39: 61$ & 5 & 11 \\
Starch & 12 & 90 & $48: 52$ & 7 & 11 \\
\hline
\end{tabular}

1as-synthesized; ${ }^{2}$ after thermal treatment; and ${ }^{3}$ average particle size calculated from XRD using Scherrer equation. 


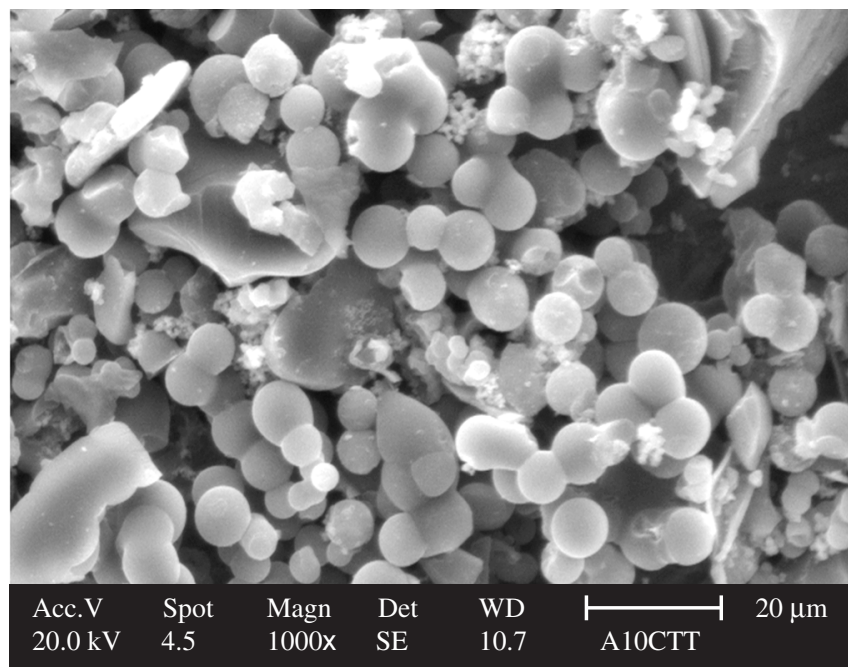

(a)

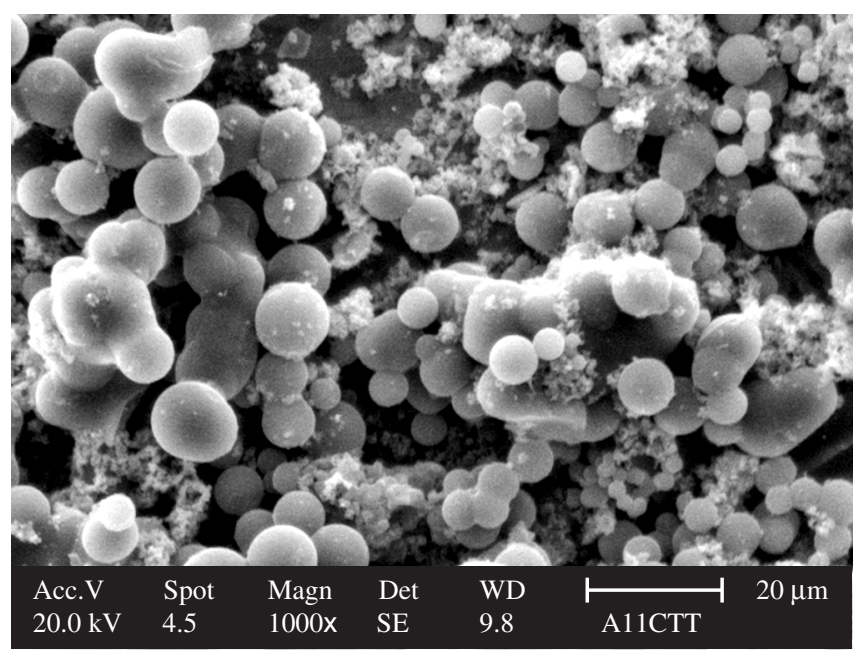

(b)

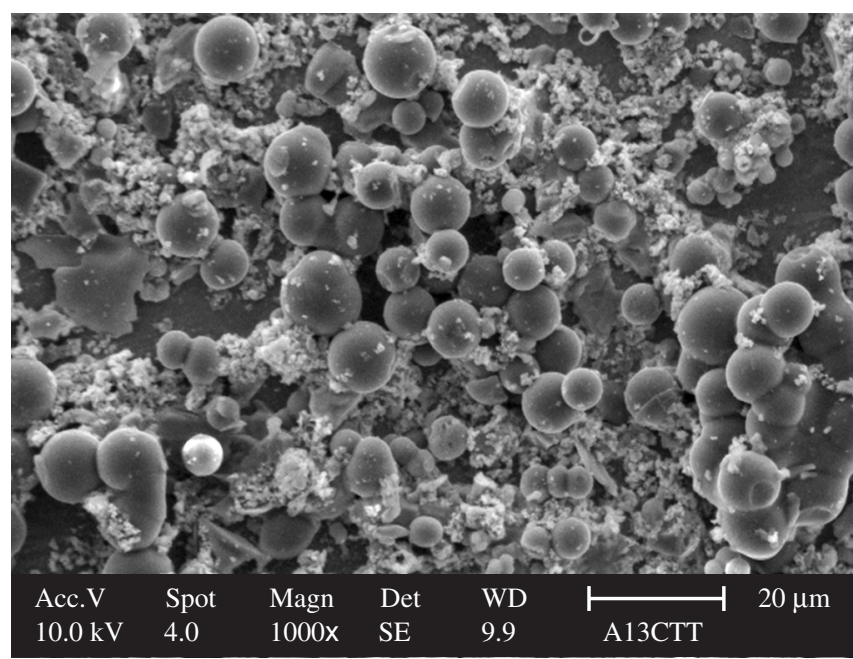

(c)

Figure 3. SEM micrographs of PtRu/Carbon materials after thermal treatment a) glucose 6 hours; b) starch 6 hours; and c) starch 12 hours.
The cyclic voltammograms of PtRu/Carbon materials in sulfuric acid medium are shown in Figure 4. For all materials the cyclic voltammograms do not have a well-defined hydrogen adsorptiondesorption region $(0-0.4 \mathrm{~V})$, as observed for materials with $\mathrm{Pt}: \mathrm{Ru}$ atomic ratio of $50: 50^{8}$. The currents in the double layer $(0.4-0.8 \mathrm{~V})$ are larger for materials prepared using starch as carbon source, suggesting the presence of more oxide species on the nanoparticles surface ${ }^{8}$. The electro-oxidation of methanol was studied varying the concentration from 0.1 to $1.0 \mathrm{~mol}^{-\mathrm{L}^{-1}}$ (Figure 5). In a general manner, for all samples in the hydrogen region $(0-0.2 \mathrm{~V})$, the currents values decrease with the increase of methanol concentration probably due to the increase of methanol adsorption on the surface ${ }^{8}$. For potentials more positive than $0.25 \mathrm{~V}$, the currents values increase with methanol concentration, even for 1.0 mol. $\mathrm{L}^{-1}$.

The PtRu/Carbon materials performances in methanol oxidation are shown in Figure 6. The anodic cyclic voltammetry responses were plotted after subtracting the background currents ${ }^{1,16,17}$ and the currents values were normalized per gram of platinum, considering that methanol adsorption and dehydrogenation occur only on platinum sites at ambient temperature ${ }^{1}$. The electro-oxidation of methanol started at aproximatelly $0.25 \mathrm{~V}$ for the materials prepared by hydrothermal carbonization while for the commercial electrocatalyst it started at $0.30 \mathrm{~V}$. The material prepared using starch and 6 hours of reaction time showed the best performance in the potential range of interest for direct methanol fuel cell $(0.2-0.6 \mathrm{~V})$.

\section{Conclusions}

The hydrothermal carbonization process using starch or glucose as carbon sources produces active PtRu/Carbon materials for methanol electro-oxidation. The Pt:Ru atomic ratios observed in the obtained materials were similar to the nominal atomic ratios used in the preparations. The $\mathrm{X}$ ray diffractograms of obtained materials showed the typical fcc structure of platinum and platinum alloys. The materials as-synthesized did not show electrocatalytic activity probably due to an incompletely polymerization and carbonization of the carbon sources in the reaction conditions. After thermal treatment an increase of the average nanoparticle size occurs and a peak at about $2 \theta=44^{\circ}$ attributed to a ruthenium phase appears. The material prepared using starch and 6 hours of reaction time showed the best performance in the potential range of interest for direct methanol fuel cell $(0.2-0.6 \mathrm{~V})$. Further work is however necessary to study the

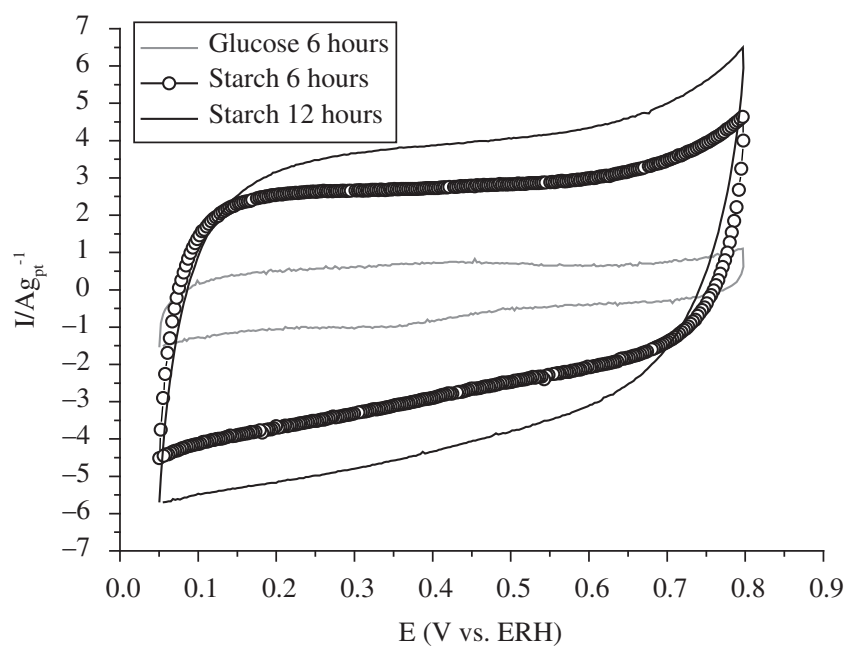

Figure 4. Cyclic voltammograms of PtRu/Carbon materials in $0.5 \mathrm{~mol} . \mathrm{L}^{-1}$ $\mathrm{H}_{2} \mathrm{SO}_{4}$ with a sweep rate of $10 \mathrm{mV} \cdot \mathrm{s}^{-1}$. 


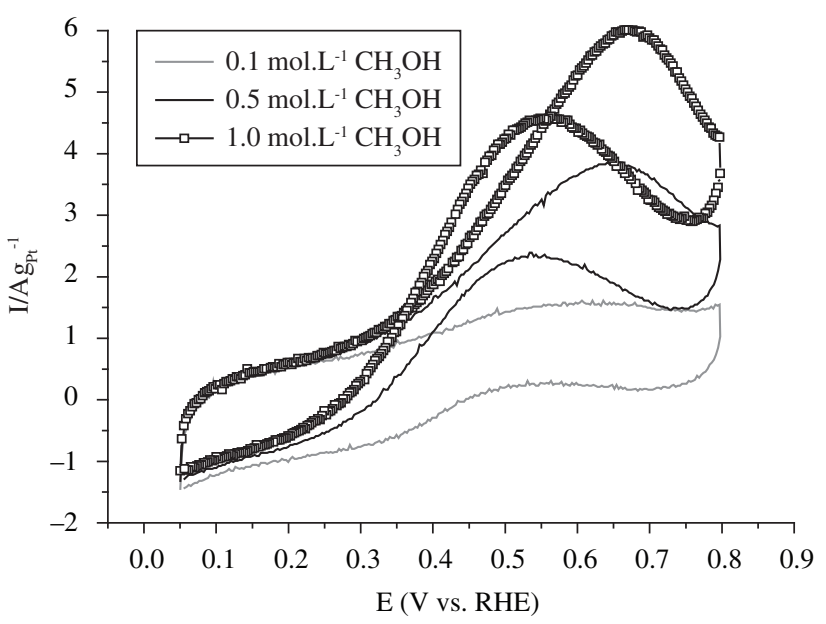

(a)

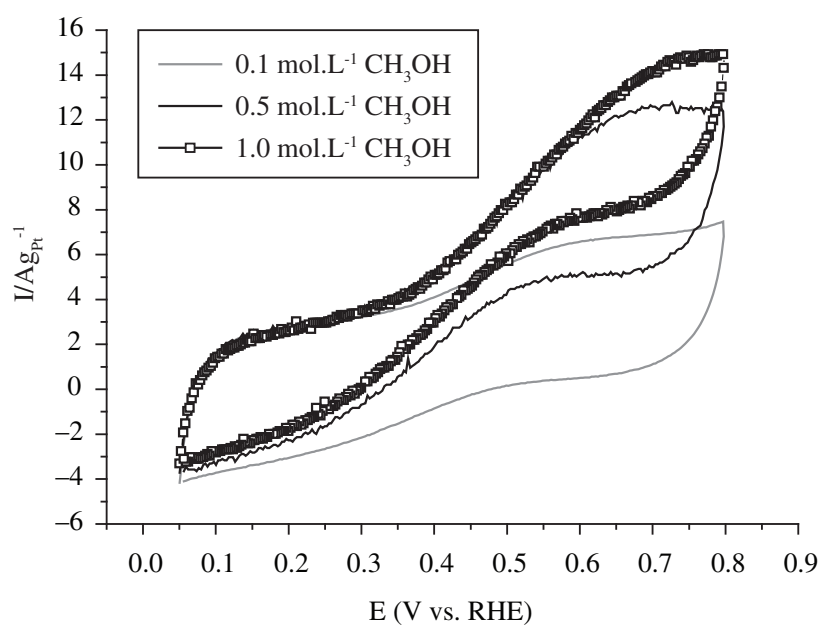

(b)

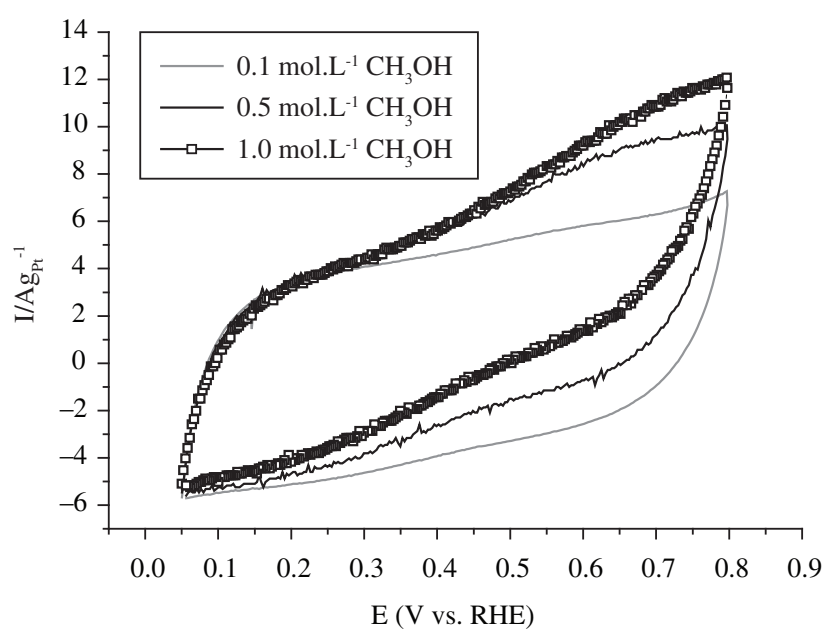

(c)

Figure 5. Cyclic voltammograms of PtRu/Carbon materials in $0.5 \mathrm{~mol} . \mathrm{L}^{-1}$ $\mathrm{H}_{2} \mathrm{SO}_{4}$ and different concentrations of methanol with a sweep rate of $10 \mathrm{mV} \cdot \mathrm{s}^{-1}$. a) glucose 6 hours; b) starch 6 hours; and c) starch 12 hours.

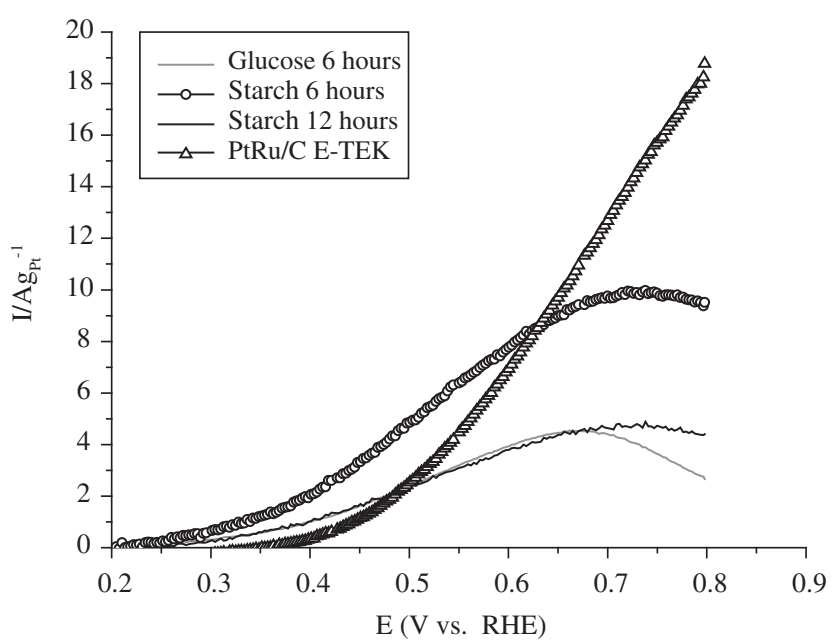

Figure 6. Cyclic voltammograms of PtRu/Carbon materials in $0.5 \mathrm{~mol} . \mathrm{L}^{-1}$ $\mathrm{H}_{2} \mathrm{SO}_{4}$ containing $1.0 \mathrm{~mol} . \mathrm{L}^{-1}$ of methanol with a sweep rate of $10 \mathrm{mV} \cdot \mathrm{s}^{-1}$, considering only the anodic sweep.

synthesis conditions in more details and to characterize the obtained materials by other techniques like transmission electron microscopy and chronoamperometry.

\section{Acknowledgments}

The authors thank Conselho Nacional de Desenvolvimento Científico e Tecnológico (CNPq), Fundação de Amparo à Pesquisa do Estado de São Paulo (FAPESP) and Conselho de Aperfeiçoamento do Ensino Superior (CAPES) for financial support.

\section{References}

1. Spinacé EV, Linardi M, Neto AO. Co-catalytic effect of nickel in the electro-oxidation of ethanol on binary Pt-Sn electrocatalysts. Electrochemistry Communications. 2005; 7(4):365-369.

2. Neto, AO, Vasconcelos TRR, Silva RWRV, Spinacé EV. Electro-oxidation of etthylene glycol on PtRu/C and PtSn/C electrocatalysts prepared by alcohol reduction process. Journal of Applied Electrochemistry. 2005; 35(2):193-198.

3. Wendt H, Linardi M, Aricó EM. Células a combustível de baixa potência para aplicações estacionárias. Química Nova. 2002; 25(3):470-476.

4. Wendt H, Götz M, Linardi M. Tecnologia de células a combustível. Química Nova. 2000; 23(4):538-546.

5. Gonzalez ER. Eletrocatálise e poluição ambiental. Química Nova. 2000; 23(2):262-266.

6. Zhou WJ, Zhou B, Li WZ, Song SQ, Sun GQ, Xin Q, Douvartzides S, Goula M, Tsiakaras P. Performance comparison of low-temperature direct alcohol fuel cells with different anode catalysts. Journal of Power Sources. 2004; 126(1-2):16-22.

7. Liu H, Song C, Zhang L, Zhang J, Wang H, Wilkinson DP. A review of anode catalysis in the direct methanol fuel cell. Journal of Power Sources. 2006; 155(2):95-110.

8. Spinacé EV, Neto AO, Vasconcelos TRR, Linardi M. Electro-oxidation of ethanol using PtRu/C electrocatalysts prepared by alcohol-reduction process. Journal of Power Sources. 2004; 137(1):17-23.

9. Serp P, Corrias M, Kalck P. Carbon nanotubes and nanofibers in catalysis. Applied Catalysis A: General. 2003; 253(2):337-358.

10. Park K-W, Sung Y-E, Han S, Yun Y, Hyeon T. Origin of the Enhanced Catalytic Activity of Carbon Nanocoil-Supported PtRu Alloy Electrocatalysts. Journal of Physical Chemistry B. 2004; 108(3):939-944. 
11. Liu YC, Qiu XP, Huang YQ, Zhu WT. Methanol electro-oxidation on mesocarbon microbead supported Pt catalysts. Carbon. 2002; 40(13):2375-2380

12. Yu S-H, Cui X, Li L, Li K, Yu B, Antonietti M, Cölfen H. From Starch to Metal/Carbon Nanostructures: Hydrothermal Metal-Catalyzed Carbonization. Advanced Materials. 2004; 16(18):1636-1640.

13. Qian H-S, Yu S-H, Luo L-B, Gong J-Y, Fei L-F, Liu X-M. Synthesis of Uniform Te@Carbon Rich Composite Nanocables with Photoluminescence Properties and Carbonaceous Nanofibers by the Hydrothermal Carbonization of Glucose. Chemistry of Materials. 2006; 18(8):2102-2108.

14. Titirici M-M, Antonietti M, Thomas A. A Generalized Synthesis of Metal Oxide Hollow Spheres using a Hydrothermal Approach. Chemistry of Materials. 2006; 18(16):3808-3812.

15. Baturina OA, Aubuchon SR, Wynne KJ. Thermal Stability in Air of Pt/C Catalysts and PEM Fuel Cell Catalyst Layers. Chemistry of Materials. 2006; 18(6):1498-1504.
16. Neto AO, Giz MJ, Perez J, Ticianelli EA, Gonzalez ER. The Electrooxidation of Ethanol on Platinum and Platinum Alloys Supported on High Surface Area Carbon. Journal of Electrochemistry Society. 2002; 149(3):272-279.

17. Colmati Jr. F, Valbuena WHL, Camara GA, Ticianelli EA, Gonzalez ER. Carbon monoxide oxidation on Pt-Ru electrocatalysts supported on high surface area carbon. Journal of the Brazilian Chemical Society. 2002; 13(4):474-482.

18. Radmilović V, Gasteiger HA, Ross PN. Structure and Chemical Composition of a Supported Pt-Ru Electrocatalyst for Methanol Oxidation. Journal of Catalysis. 1995; 154(2):98-106.

19. Antolini E, Caderllini F. Formation of carbon supported PtRu alloys: an XRD analysis. Journal of Alloys and Compounds. 2001; 315(2):118-122. 